\title{
PENGARUH MENTAL ACCOUNTING DAN PSYCHOLOGICAL FACTORS TERHADAP PERILAKU KONSUMEN DALAM PENGGUNAAN KARTU KREDIT
}

\author{
Ratih Dewi Titisari Haryana \\ Sekolah Tinggi Ilmu Ekonomi "Urip Sumoharjo" Surabaya \\ r.dewi017@gmail.com
}

\begin{abstract}
ABSTRAK
Penelitian ini bertujuan untuk mengetahui pengaruh mental accounting dan pshycological factors terhadap perilaku konsumen dalam penggunaan kartu kredit. Metode analisis menggunakan regresi linear berganda dengan pengambilan sampel menggunakan teknik convenience sampling dimana diperoleh 112 responden. Hasil penelitian menyimpulkan bahwa ketiga indikator dari mental accounting yaitu mental budget, self control dan short term orientation memiliki pengaruh yang signifikan terhadap perilaku konsumen dalam penggunaan kartu kredit. Pada pshycological factors hanya emotional instability, conscientiousness, materialism dan debt adverse yang berpengaruh signifikan sedangkan pada introvertion dan need for arousal tidak memiliki pengaruh yang signifikan terhadap perilaku konsumen dalam penggunaan kartu kredit.
\end{abstract}

Kata kunci: mental accounting, pshycological factors, perilaku konsumen, kartu kredit.

\section{PENDAHULUAN}

Kartu kredit telah menjadi lifestyle pada era modern yang serba cepat saat ini. Kartu kredit mampu memberikan keuntungan, alasannya tak lain adalah mampu menunjukkan kemudahan bagi penggunanya. Dengan menggunakan kartu kredit pembayaran yang dilakukan terasa lebih cepat dan lebih mudah dibandingkan menggunakan uang tunai atau cek. Penggunaan kartu kredit telah menjadi hal umum dikarenakan adanya peningkatan transaksi tanpa uang tunai, termasuk electronic banking dan belanja online yang saat ini banyak digemari masyarakat. Menurut penelitian Hirschman (1979) seseorang yang menggunakan kartu kreditnya justru akan lebih banyak melakukan pembelian (impulsive) ketika dirinya berbelanja di departement store.

Sikap konsumen terhadap penggunaan kartu kredit dalam hal pembelian telah menjadi menguntungkan dari waktu ke waktu. Sifat kartu kredit yang praktis dan mudah serta memiliki prinsip "buy now pay later" telah memikat banyak orang. Black and Morgan (1998) menemukan bahwa 
kebanyakan pemegang kartu kredit menggunakan kartu kreditnya untuk menutupi pengeluaran yang sifatnya digunakan dalam kehidupan sehari-hari. Menariknya, tidak ada sama sekali yang bertujuan atau melibatkan penggunaan kartu kredit untuk pembiayaan aset. Dengan demikian, terlihat bahwa mereka lebih memilih melakukan pembayaran yang sifatnya tertunda dan menanggung tagihan kartu kredit dengan suku bunga yang relatif tinggi.

Beberapa pakar ekonomi berpendapat bahwa penggunaan penggunaan kartu kredit yang terus menerus dan cenderung berulang memberikan kesan bahwa konsumen bertindak secara tidak masuk akal (irasional). Fenomena ini menjelaskan bahwa konsumen lebih berfikir mengenai kemudahan dari penggunaan kartu kredit saja bukan berfikir mengenai berapa banyak hutang yang nantinya harus ditanggung. Perilaku irrasional dalam penggunaan kartu kredit dapat dikatakan bahwa tindakan individu tersebut dipengaruhi oleh mental accounting. Mental accounting didefinisikan sebagai perilaku kognitif seseorang dimana mereka menggolongkan antara masukan dan keluaran berdasarkan pos-pos tertentu seperti halnya model akuntansi (Thaler and Shefrin, 1981). Pada hakikatnya, setiap individu dituntut untuk mengedepankan rasionalitasnya sehingga tidak mengarah pada pengambilan keputusan yang tidak optimal.

Fenomena mental accounting terhadap penggunaan kartu kredit merupakan tema yang menarik untuk diteliti terutama bagi masyarakat yang hidup di kota besar seperti Surabaya. Perilaku yang bersifat "overspending" dalam penggunaan kartu kredit dapat menyebabkan peningkatan hutang. Pengelolaan keuangan yang baik merupakan satu-satunya cara agar seseorang mampu menggunakan kartu kreditnya secara bijak sehingga terhindar dari hutang yang menyulitkan, serta mampu mempersiapkan tabungan dan investasi di masa mendatang. Selain pengaruh mental accounting faktor psikologi juga turut memberikan andil dalam mempengaruhi penggunaan kartu kredit. Faktor psikologi tersebut meliputi personality traits dan attitude toward debt. Perlunya ditumbuhkan pemahaman terhadap masyarakat modern mengenai kartu kredit tak lain adalah untuk menurunkan hutang yang mereka miliki. Sikap seperti inilah yang seharusnya 
dimiliki oleh setiap individu dimana mereka harus lebih berhati-hati terhadap kredit/hutang sehingga mereka tidak akan terjebak pada pengelolaan keuangan yang buruk.

Tujuan penelitian ini adalah untuk memprediksi dan menjelaskan bahwa mental accounting dan psychological factors memiliki pengaruh terhadap perilaku seseorang dalam penggunaan kartu kredit Hasil penelitian diharapkan dapat menambah khasanah keilmuan di bidang akuntansi yang membuktikan bahwa mental accounting pada hakikatnya dapat berimplikasi positif jika diterapkan dengan baik terutama dalam hal penggunaan kartu kredit. Mental accounting yang merupakan ilmu di bidang akuntansi keprilakuan pada dasarnya berhubungan langsung dengan ilmu psikologi sehingga pada penelitian ini akan diteliti adanya faktor-faktor psikologi terhadap penggunaan kartu kredit.

\section{KERANGKA KONSEPTUAL DAN HIPOTESIS}

Kerangka konseptual yang digunakan di dalam penilitian ini dapat digambarkan sebagai berikut:

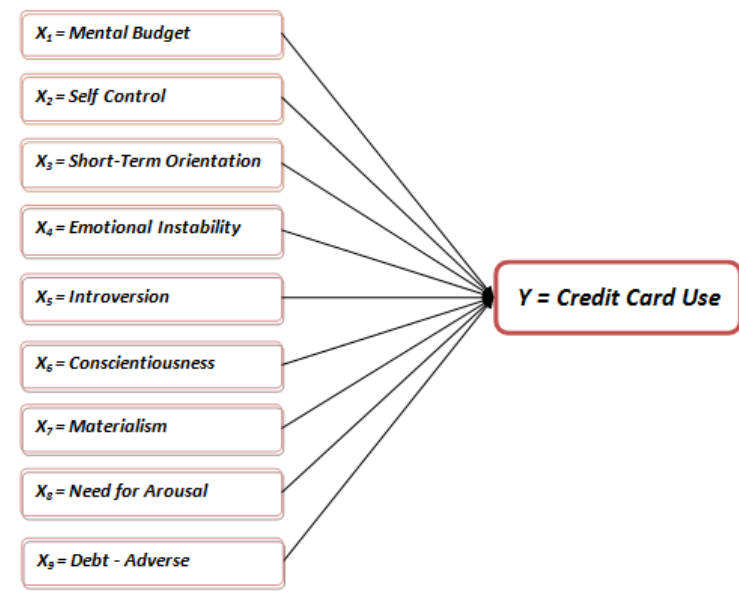

Gambar 1. Kerangka Konseptual

Berdasarkan kerangka konseptual di atas maka hipotesis yang digunakan di dalam penelitian ini adalah sebagai berikut:

$\mathrm{H}_{1}$ : Semakin tinggi mental budget seseorang maka semakin menurunkan penggunaan kartu kredit.

$\mathrm{H}_{2}$ : Semakin tinggi self control seseorang maka semakin menurunkan penggunaan kartu kredit.

$\mathrm{H}_{3}$ : Semakin tinggi short term orientation seseorang maka semakin meningkatkan penggunaan kartu kredit.

$\mathrm{H}_{4}$ : Semakin tinggi sifat emotional instability seseorang maka semakin meningkatkan penggunaan kartu kredit. 
$\mathrm{H}_{5}$ : Semakin tinggi sifat introversion seseorang maka semakin meningkatkan penggunaan kartu kredit.

$\mathrm{H}_{6}$ : Semakin tinggi sifat conscientiousness seseorang maka semakin menurunkan penggunaan kartu kredit.

$\mathrm{H}_{7}$ : Semakin tinggi sifat materialism seseorang maka semakin meningkatkan penggunaan kartu kredit.

$\mathrm{H}_{8}$ : Semakin tinggi sifat need for arousal seseorang maka semakin meningkatkan penggunaan kartu kredit.

$\mathrm{H}_{9}$ : Semakin tinggi sifat debt adverse seseorang maka semakin meningkatkan penggunaan kartu kredit.

\section{METODOLOGI PENELITIAN}

Penelitian ini menggunakan pendekatan kuantitatif dengan menggunakan data primer. Subyek penelitian adalah konsumen yang menggunakan kartu kredit ketika berbelanja. Kartu kredit yang digunakan oleh dapat beragam seperti kartu kredit Bank Mandiri, Bank BCA, Bank Mega, HSBC dan lain sebagainya. Teknik pengumpulan data yang dilakukan dengan menggunakan metode survey dengan cara penyebaran kuesioner. Populasi di dalam penelitian ini adalah seluruh pengunjung Tunjungan Plaza Surabaya yang menggunakan kartu kreditnya sebagai alat transaksi pembayaran ketika berbelanja dengan jumlah yang tidak diketahui secara pasti sehingga populasi ini disebut sebagai populasi infinite. Oleh karena populasi yang digunakan di dalam penelitian ini tidak dapat diketahui (infinite) maka pengambilan sampel dilakukan dengan cara menggunakan rumus sebagai berikut:

$$
n=\frac{Z_{\propto}{ }^{2} \cdot p \cdot q}{d^{2}}
$$

dimana,

$$
\begin{aligned}
& \mathrm{n}=\text { Besar sampel } \\
& \mathrm{p}=\text { Estimator proporsi populasi (jika }
\end{aligned}
$$
tidak diketahui dianggap $50 \%=$ $0,5)$

$$
\begin{aligned}
\mathrm{q}= & 1-\mathrm{p}(100 \%-\mathrm{p}) \\
\mathrm{Z}_{\alpha}{ }^{2}= & \text { Harga kurva normal yang } \\
& \text { tergantung dari alpha }\left(\mathrm{Z}_{\alpha} 0.05=\right. \\
& 1,96) \\
\mathrm{d}= & \text { Toleransi kesalahan yang dipilih, } \\
& \text { menggunakan batas kesalahan } \\
& \text { sebesar } 10 \%(\mathrm{~d}=0.1) \text { yang berarti } \\
& \text { tingkat akurasi sebesar } 90 \% .
\end{aligned}
$$


Dengan menggunakan rumus di atas maka diperoleh jumlah sampel minimal sebanyak:

$$
\begin{aligned}
n & =\frac{Z_{\propto}{ }^{2} \cdot p \cdot q}{d^{2}} \\
n & =\frac{(1.96)^{2} \cdot(0.5) \cdot(0.5)}{(0.1)^{2}} \\
& =\frac{0.9604}{0.01}=96,04
\end{aligned}
$$

(minimal jumlah sampel 96 responden)

Teknik pengambilan sampel dalam penelitian ini adalah convenience sampling yang merupakan teknik pengambilan sampel yang berdasarkan pada kemudahan saja. Responden yang diambil sebagai sampel dikarenakan responden tersebut kebetulan berada di dalam lokasi penelitian (Tunjungan Plaza Surabaya), memenuhi kriteria (menggunakan kartu kredit ketika berbelanja) serta dengan senang hati bersedia untuk membantu peneliti dalam mengisi kuesioner yang diberikan.

Di dalam penelitian ini variabel yang digunakan adalah variabel independen $(\mathrm{X})$ adalah sebagai berikut:

1. Mental Accounting meliputi komponen yang terdiri dari :

- Mental budget $\left(\mathrm{X}_{1}\right)$

- Self Control $\left(\mathrm{X}_{2}\right)$

- $\quad$ Short-Term Orientation $\left(\mathrm{X}_{3}\right)$
(Perry, 2000)

2. Psychological Factors meliputi komponen yang terdiri dari :

- Personality Traits terdiri dari :

a. Emotional Instability $\left(\mathrm{X}_{4}\right)$

b. Introversion $\left(\mathrm{X}_{5}\right)$

c. Conscientiousness $\left(\mathrm{X}_{6}\right)$

d. Materialism $\left(\mathrm{X}_{7}\right)$

e. Need for Arousal $\left(\mathrm{X}_{8}\right)$

- Attitude toward Debt yang mencangkup Debt - Adverse $\left(\mathrm{X}_{9}\right)$

(Pirog and Robert, 2007 dan Lea et. al, 1995)

Sedangkan yang menjadi variabel dependen $(\mathrm{Y})$ adalah perilaku konsumen dalam hal penggunaan kartu kredit (credit card use) yang diukur berdasarkan kerasionalan individu dalam penggunaan kartu kredit (D'Astous, 1990).

Instrumen penelitian ini adalah kuesioner dengan pengukuran variabel yang menggunakan "Skala Likert". Skala likert digunakan untuk mengukur sikap ataupun respon dari seseorang terhadap suatu objek yang akan diteliti. Skala likert terdiri dari kumpulan pertanyaan atau pernyataan yang telah dirancang oleh peneliti dimana responden akan menjawab pertanyaan atau pernyataan tersebut sesuai pribadi masing-masing 
tanpa ada jawaban yang benar atau salah. Jawaban responden atas pertanyaan atau pernyataan tersebut berupa pemilihan jawaban "setuju" atau "tidak setuju". Pada penelitian ini skala likert yang akan digunakan adalah sebagai berikut:

Tabel 1. Pengukuran Variabel

\begin{tabular}{|c|c|}
\hline Sangat Tidak Sesuai (STS) & 1 \\
\hline Tidak Sesuai (TS) & 2 \\
\hline Ragu - Ragu (R) & 3 \\
\hline Sesuai (S) & 4 \\
\hline Sangat Sesuai (SS) & 5 \\
\hline
\end{tabular}

Peneliti menggunakan analisis regresi berganda untuk meneliti pengaruh mental accounting dan psychological factors terhadap perilaku konsumen dalam penggunaan kartu kredit. Proses pengolahan data menggunakan program SPSS.

Tahapan yang dilalui adalah sebagai berikut:

1. Uji Validitas

Uji validitas pada dasarnya digunakan untuk mengukur kevalidan atas kuesioner yang telah diajukan sebelumnya. Kriteria data dikatakan valid jika korelasi $r$ hitung $>\mathrm{r}$ tabel, sedangkan data dikatakan tidak valid jika korelasi $r$ hitung $<r$ tabel.
2. Uji Reliabilitas

Uji reliabilitas dapat dilakukan setelah uji validitas. Uji reliabilitas hanya dapat digunakan pada pertanyaan-pertanyaan dari kuesioner yang telah dianggap valid. Uji reliabilitas merupakan suatu indeks yang dapat menunjukkan sejauh mana suatu pengukuran dapat dipercaya. Pada penelitian ini, uji reliabilitas dapat dilihat dari nilai cronbach alpha $(\alpha)$. Suatu variabel dikatakan reliabel jika memberikan nilai cronbach alpha $(\alpha)>0,6$ sedangkan dikatakan tidak reliabel jika nilai cronbach alpha $(\alpha)<0,6$.

3. Regresi Linear Berganda

Dalam penelitian ini terdapat sembilan variabel independent dan satu variabel dependent. Untuk dapat mengetahui adanya pengaruh antara variabel independent terhadap variabel dependent maka digunakan pengujian hipotesis dengan metode analisis data Multiple Linear Regression (regresi linier berganda). Analisis regresi linier berganda digunakan di dalam penelitian ini dikarenakan terdapat variabel independent yang lebih dari satu. Sehingga, persamaan regresi linier 
berganda dapat dituliskan sebagai berikut:

$$
\begin{array}{rl}
C C=\beta_{0}+\beta_{1} & M B+\beta_{2} S C+\beta_{3} S T \\
& +\beta_{4} E I+\beta_{5} I N \\
& +\beta_{6} C O+\beta_{7} M A \\
& +\beta_{8} N A+\beta_{9} D A+\varepsilon
\end{array}
$$

Dimana,

$$
\begin{aligned}
& \mathrm{Y}=\text { Credit Card Use } \\
& \mathrm{X}_{1}=\mathrm{MA}=\text { Mental Budget } \\
& \mathrm{X}_{2}=\mathrm{SC}=\text { Self Control } \\
& \mathrm{X}_{3}=\mathrm{ST}=\text { Short }- \text { Term } \\
& \text { Orientation } \\
& \mathrm{X}_{4}=\mathrm{EI}=\text { Emotional Instability } \\
& \mathrm{X}_{5}=\mathrm{IN}=\text { Introversion } \\
& \mathrm{X}_{6}=\mathrm{CO}=\text { Conscientiousness } \\
& \mathrm{X}_{7}=\mathrm{MA}=\text { Materialism } \\
& \mathrm{X}_{8}=\mathrm{NA}=\text { Need for Arousal } \\
& \mathrm{X}_{9}=\mathrm{AD}=\text { Debt }- \text { Adverse }
\end{aligned}
$$

4. Uji Koefisien Determinasi $\left(\mathrm{R}^{2}\right)$

Koefisien determinasi $\left(\mathrm{R}^{2}\right)$ digunakan untuk mengukur seberapa jauh kemampuan suatu model dalam menjelaskan variable - variabel terikat. Nilai koefisien determinasi diukur oleh nilai R-Square atau Adjusted R-Square. Nilai koefisien determinasi berkisar antara nol dan satu. Nilai $\mathrm{R}^{2}$ yang kecil berarti bahwa kemampuan variabel independen dalam menjelaskan variabel dependen dapat dikatakan amat terbatas. Akan tetapi jika nilai $\mathrm{R}^{2}$ mendekati satu maka dapat dikatakan bahwa variabel independen tersebut mampu memberikan keseluruhan informasi yang dibutuhkan untuk memprediksi variabel dependen.

5. Uji Kelayakan Model (Uji F)

Uji kelayakan model atau yang lebih dikenal sebagai uji $\mathrm{F}$ merupakan tahapan awal untuk mengidentifikasi model regresi yang diestimasi layak atau tidak. Kelayakan yang dimaksudkan apakah model yang diestimasi layak digunakan untuk menjelaskan pengaruh variable - variabel independen (bebas) terhadap variabel dependen (terikat). Apabila nilai prob. $\mathrm{F}$ hitung (pada ouput SPSS akan ditunjukkan pada kolom sig.) lebih kecil dari tingkat kesalahan/error (alpha) maka model regresi yang diestimasi layak, sedangkan apabila nilai prob. $\mathrm{F}$ hitung lebih besar dari tingkat kesalahan/error (alpha) maka model regresi yang diestimasi tidak layak. 
6. Uji Hipotesis (Uji t)

Hipotesis di dalam penelitian ini diuji dengan menggunakan T-test (uji t) dimana uji t ini dimaksudkan untuk melihat signifikansi antara variabel independen dengan variabel dependen. Uji statistik t menunjukan seberapa jauh pengaruh masingmasing variabel independen secara parsial/individual mempunyai pengaruh yang signifikan atau tidak terhadap variabel dependen. Uji $\mathrm{t}$ dalam regresi linier berganda dimaksudkan untuk menguji apakah parameter (koefisien regresi dan konstanta) yang diduga untuk mengestimasi persamaan/model regresi linier berganda sudah merupakan parameter yang tepat atau belum. Apabila nilai prob. $\mathrm{t}$ hitung (ouput SPSS ditunjukkan pada kolom sig.) lebih kecil dari tingkat kesalahan/error (alpha) maka dapat dikatakan bahwa variabel independen berpengaruh signifikan terhadap variabel dependen, sedangkan apabila nilai prob. $\mathrm{t}$ hitung lebih besar dari tingkat kesalahan/error (alpha) maka variabel independen tidak berpengaruh signifikan terhadap variabel dependen.

\section{HASIL PENELITIAN DAN PEMBAHASAN}

\subsection{Uji Validitas dan Reliabilitas}

Uji validitas merupakan pengujian yang menunjukkan sejauh mana ketepatan dan kecermatan suatu alat ukur dalam melakukan fungsi pengukurannya. Pengujian ini dilakukan dengan cara mengkorelasikan skor item dengan skor total variabel. Bagian dari uji validitas yang dipakai dalam penelitian adalah melalui analisis item-item pertanyaan.

Dalam penelitian ini data yang diuji adalah sebanyak 112 responden dengan menggunakan software SPSS 20. for windows. Item atau indikator dikatakan valid jika hasil angka korelasi product moment Pearson ( $r$ hitung) pada level signifikansi $<0,01$ dan instrumen di dalam penelitian dapat dikatakan valid jika nilai koefisien korelasinya lebih besar dari 0.3 . Hasil pengujian validitas ditunjukkan pada Tabel 2 di bawah ini. 
Tabel 2. Hasil Uji Validitas

\begin{tabular}{|c|c|c|c|c|}
\hline Variabel & $\begin{array}{l}\text { Indikator } \\
\text { Item }\end{array}$ & $\begin{array}{l}\text { Koefisien } \\
\text { Korelasi }\end{array}$ & Signifilkansi & Keterangan \\
\hline \multirow{5}{*}{ Mental Budget $\left(\mathrm{X}_{\mathrm{i}}\right)$} & $\mathrm{X}_{1.1}$ & 0.791 & 0.000 & Valid \\
\hline & $\mathrm{X}_{1: 2}$ & 0.839 & 0.000 & Valid \\
\hline & $\mathrm{X}_{1: 3}$ & 0.798 & 0.000 & Valid \\
\hline & $\mathrm{X}_{\mathrm{L} .4}$ & 0.825 & 0.000 & Valid \\
\hline & $X_{1.5}$ & 0.693 & 0.000 & Valid \\
\hline \multirow{4}{*}{ Self Control $\left(\mathrm{X}_{2}\right)$} & $\mathrm{X}_{21}$ & 0.778 & 0.000 & Valid \\
\hline & $X_{28}$ & 0.840 & 0.000 & Valid \\
\hline & $\mathrm{X}_{23}$ & 0.783 & 0.000 & Valid \\
\hline & $\mathrm{X}_{24}$ & 0.677 & 0.000 & Valid \\
\hline \multirow{4}{*}{$\begin{array}{c}\text { Short-Term } \\
\text { Orientation }\left(\mathrm{X}_{\mathrm{z}}\right)\end{array}$} & $X_{i 1}$ & 0.677 & 0.000 & Valid \\
\hline & $\mathrm{X}_{\mathrm{i} 2}$ & 0.733 & 0.000 & Valid \\
\hline & $\mathrm{X}_{\mathrm{i}: 3}$ & 0.767 & 0.000 & Valid \\
\hline & $\mathrm{X}_{\mathrm{i}, 4}$ & 0.740 & 0.000 & Valid \\
\hline \multirow{4}{*}{$\begin{array}{c}\text { Emotional Instability } \\
\qquad\left(\mathrm{X}_{4}\right)\end{array}$} & $\mathrm{X}_{\mathrm{L} 1}$ & 0.564 & 0.000 & Valid \\
\hline & $\mathrm{X}_{4:}$ & 0.823 & 0.000 & Valid \\
\hline & $\mathrm{X}_{42}$ & 0.825 & 0.000 & Valid \\
\hline & $\bar{X}_{44}$ & 0.813 & 0.000 & Valid \\
\hline \multirow{3}{*}{ Introversion $\left(\mathrm{X}_{s}\right)$} & $\mathrm{X}_{\mathrm{s}: 1}$ & 0.821 & 0.000 & Valid \\
\hline & $\mathrm{X}_{\mathrm{s}:}$ & 0.856 & 0.000 & Valid \\
\hline & $\mathrm{X}_{s:}$ & 0.798 & 0.000 & Valid \\
\hline \multirow{3}{*}{$\begin{array}{c}\text { Conscientiousness } \\
\left(\mathrm{X}_{6}\right)\end{array}$} & $\mathrm{X}_{61}$ & 0.923 & 0.000 & Valid \\
\hline & $\mathrm{X}_{62}$ & 0.880 & 0.000 & Valid \\
\hline & $X_{63}$ & 0.866 & 0.000 & Valid \\
\hline \multirow{4}{*}{ Materialism (X,) } & $\mathrm{X}_{n 1}$ & 0.874 & 0.000 & Valid \\
\hline & $\mathrm{X}_{72}$ & 0.885 & 0.000 & Valid \\
\hline & $\mathrm{X}_{73}$ & 0.843 & 0.000 & Valid \\
\hline & $\mathrm{X}_{2.4}$ & 0.867 & 0.000 & Valid \\
\hline \multirow{4}{*}{$\begin{array}{l}\text { Need for Arousal } \\
\left(\mathrm{X}_{\mathrm{s}}\right)\end{array}$} & $X_{41}$ & 0.780 & 0.000 & Valid \\
\hline & $\mathrm{X}_{\mathrm{I}:}$ & 0.722 & 0.000 & Valid \\
\hline & $\mathrm{X}_{\mathrm{4}}$ & 0.833 & 0.000 & Valid \\
\hline & $\mathrm{X}_{\mathrm{I} 4}$ & 0.773 & 0.000 & Valid \\
\hline \multirow{3}{*}{ Debt Adverse $\left(\mathrm{X}_{f}\right)$} & $\mathrm{X}_{0.1}$ & 0.780 & 0.000 & Valid \\
\hline & $\mathrm{X}_{9.2}$ & 0.839 & 0.000 & Valid \\
\hline & $\mathrm{X}_{83}$ & 0.750 & 0.000 & Valid \\
\hline \multirow{7}{*}{ Credit Card Use (Y) } & $Y_{1.1}$ & 0.862 & 0.000 & Valid \\
\hline & $Y_{12}$ & 0.821 & 0.000 & Valid \\
\hline & $Y_{1: 2}$ & 0.855 & 0.000 & Valid \\
\hline & $Y_{1.4}$ & 0.587 & 0.000 & Valid \\
\hline & $\mathrm{Y}_{1, s}$ & 0.819 & 0.000 & Valid \\
\hline & $Y_{1.6}$ & 0.778 & 0.000 & Valid \\
\hline & $Y_{17}$ & 0.616 & 0.000 & Valid \\
\hline
\end{tabular}

Hasil pengujian validitas menunjukkan bahwa item-item pertanyaan pada variabel independen dan dependen yaitu mental budget $\left(\mathrm{x}_{1}\right)$, self control $\left(\mathrm{x}_{2}\right)$, short term orientation $\left(\mathrm{x}_{3}\right)$, emotional instability $\left(\mathrm{x}_{4}\right)$, introvertion $\left(\mathrm{x}_{5}\right)$, conscientiousness $\left(\mathrm{x}_{6}\right)$, materialism $\left(\mathrm{x}_{7}\right)$, need for arousal $\left(\mathrm{x}_{8}\right)$, debt adverse $\left(\mathrm{x}_{9}\right)$ dan credit card use (y) menunjukkan bahwa seluruh item pertanyaan untuk variabel independen mempunyai nilai $r$ yang lebih besar dari $0.3(r>0.3)$ dan mempunyai nilai probabilitas lebih kecil dari 0,01 ( $\alpha<$
0.01) sehingga dinyatakan bahwa data yang dihasilkan adalah "valid".

Uji reliabilitas digunakan untuk mengetahui apakah instrumen penelitian yang berupa kuesioner tersebut handal atau konsisten, jika kehandalan (konsistensi) tersebut dapat dibuktikan maka dapat dikatakan bahwa instrumen tersebut sudah baik. Pengukuran reliabilitas menggunakan metode cronbatch's alpha dengan menggunakan indeks numerik yang disebut koefisien. Analisis reliabilitas dilakukan dengan cara melihat apakah koefisien cronbatch's alpha lebih besar dari 0,60. Jika koefisien cronbatch's alpha menunjukkan nilai lebih besar dari 0,60 maka dapat dikatakan bahwa variabel yang diukur tersebut reliabel atau memiliki kehandalan untuk digunakan dalam suatu penelitian.

Tabel 3. Hasil Uji Reliabilitas

\begin{tabular}{|l|c|c|}
\hline \multicolumn{1}{|c|}{ Variabel } & $\begin{array}{c}\text { Reliabilitas } \\
\text { (Cronbach's Alpha) }\end{array}$ & Keterangan \\
\hline Mental Budget $\left(\mathrm{X}_{1}\right)$ & 0.847 & Reliabel \\
\hline Self Control $\left(\mathrm{X}_{2}\right)$ & 0.769 & Reliabel \\
\hline Short Term Orientation $\left(\mathrm{X}_{3}\right)$ & 0.705 & Reliabel \\
\hline Emotional Instability $\left(\mathrm{X}_{4}\right)$ & 0.756 & Reliabel \\
\hline Introversion $\left(\mathrm{X}_{5}\right)$ & 0.764 & Reliabel \\
\hline Conscientiousness $\left(\mathrm{X}_{6}\right)$ & 0.868 & Reliabel \\
\hline Materialism $\left(\mathrm{X}_{7}\right)$ & 0.890 & Reliabel \\
\hline Need for Arousal $\left(\mathrm{X}_{8}\right)$ & 0.780 & Reliabel \\
\hline Debt Adverse $\left(\mathrm{X}_{9}\right)$ & 0.697 & Reliabel \\
\hline Credit Card Use $(\mathrm{Y})$ & 0.881 & Reliabel \\
\hline
\end{tabular}

Berdasarkan Tabel 3 diatas menunjukkan bahwa koefisien cronbatch's alpha pada semua item 
pertanyaan untuk variabel independen (mental budget $\left(\mathrm{x}_{1}\right)$, self control $\left(\mathrm{x}_{2}\right)$, short term orientation $\left(\mathrm{x}_{3}\right)$, emotional instability $\left(\mathrm{x}_{4}\right)$, introvertion $\left(\mathrm{x}_{5}\right)$, conscientiousness $\left(\mathrm{x}_{6}\right)$, materialism $\left(\mathrm{x}_{7}\right)$, need for arousal $\left(\mathrm{x}_{8}\right)$ dan debt adverse $\left(\mathrm{x}_{9}\right)$ ) dan dependen (credit card use $(\mathrm{y})$ ) seluruhnya menunjukkan nilai lebih dari 0,60 . Dengan demikian seluruh variabel baik independen maupun dependen dinyatakan memiliki reliabilitas /kehandalan yang baik, "reliabel".

\subsection{Uji Regresi Linier Berganda}

Pengujian hipotesis di dalam penelitian ini menggunakan teknik analisis regresi linear berganda. Pemilihan teknik tersebut berdasarkan tujuan penelitian yaitu untuk mengetahui pengaruh variabel independen yang berjumlah lebih dari satu terhadap variabel dependen dengan menggunakan data berskala interval. Berdasarkan perhitungan dari regresi linear berganda maka diperoleh hasil sebagaimana ditunjukkan pada Tabel 4 di bawah ini.

Tabel 4. Hasil Uji Regresi Linear Berganda

\begin{tabular}{|c|c|c|c|c|c|}
\hline \multicolumn{6}{|c|}{$\begin{array}{c}\mathrm{Y}=1.619-0.164 \mathrm{MB}-0.155 \mathrm{SC}+0.375 \mathrm{ST}+0.176 \mathrm{EI}-0.057 \mathrm{IN}-0.214 \mathrm{CO}+ \\
0.147 \mathrm{MA}-0.110 \mathrm{NA}+0.464 \mathrm{DA}+\varepsilon\end{array}$} \\
\hline \multirow{2}{*}{ Variabel } & \multicolumn{2}{|c|}{ Koefisien } & \multirow{2}{*}{ t hit. } & \multirow{2}{*}{ Sign } & \multirow{2}{*}{ Keterangan } \\
\hline & Koef. Reg. & Beta & & & \\
\hline Konstanta & 1.619 & & 3.512 & 0.001 & \\
\hline Mental Budget & -0.164 & -0.149 & -1.735 & 0.086 & Signifikan \\
\hline Self Control & -0.155 & -0.132 & -1.823 & 0.071 & Signifikan \\
\hline Short Term Orientation & 0.375 & 0.263 & 3.991 & 0.000 & Signifikan \\
\hline Emotional Instability & 0.176 & 0.161 & 2.117 & 0.037 & Signifikan \\
\hline Introversion & -0.057 & -0.046 & -0.670 & 0.504 & Tidak Signifikan \\
\hline Conscientiousness & -0.214 & -0.230 & -2.618 & 0.010 & Signifikan \\
\hline Materialism & 0.147 & 0.158 & 2.370 & 0.020 & Signifikan \\
\hline Need for Arousal & -0.110 & -0.090 & -1.508 & 0.135 & Tidak Signifikan \\
\hline Debt Adverse & 0.464 & 0.430 & 7.332 & 0.000 & Signifikan \\
\hline $\begin{array}{l}\text { Multiple }(\mathrm{R})=0.837 \\
\mathrm{R} \text { Square }=0.700\end{array}$ & & $\begin{array}{l}\text { F Hitung } \\
\text { Sign }\end{array}$ & $\begin{array}{l}=26.435 \\
=0.000\end{array}$ & & $\mathrm{~N}=112$ \\
\hline
\end{tabular}

Analisis korelasi ganda digunakan untuk mengetahui hubungan antara dua atau lebih variabel independen $\left(\mathrm{X}_{1}\right.$, $\mathrm{X}_{2}, \ldots, \mathrm{X}_{\mathrm{n}}$ ) terhadap variabel dependen (Y) secara serentak. Nilai koefisien korelasi berganda (R) menunjukkan seberapa besar hubungan yang terjadi antara variabel independen terhadap variabel dependen berkisar antara 0 sampai dengan 1. Nilai R yang semakin mendekati 1 menunjukkan hubungan yang terjadi semakin kuat sebaliknya nilai $\mathrm{R}$ yang mendekati 0 menunjukkan hubungan yang terjadi semakin lemah. 
Interpretasi terhadap nilai koefisien korelasi menurut Sugiyono (2010) adalah sebagai berikut:

$$
\begin{aligned}
& 0,000-0,199=\text { sangat rendah } \\
& 0,200-0,399=\text { rendah } \\
& 0,400-0,599=\text { sedang } \\
& 0,600-0,799=\text { kuat } \\
& 0,800-1,000=\text { sangat kuat }
\end{aligned}
$$

Pada penelitian ini nilai koefisien korelasi berganda atau multiple (R) yang diperoleh dari hasil analisis korelasi berganda (ditunjukkan pada tabel 4) adalah sebesar 0,837. Nilai koefisien korelasi berganda berada di antara 0,800-1,000 dimana dapat dikatakan bahwa terjadi hubungan yang sangat kuat antara mental accounting dan faktor psychology terhadap perilaku konsumen dalam penggunaan kartu kredit.

Analisis determinasi dilihat dari koefisien determinasi yang ditunjukkan pada nilai $\mathrm{R}^{2}$. Nilai $\mathrm{R}^{2}$ berkisar antara 0 sampai 1, semakin mendekati 1 maka semakin baik kemampuan dari variabel independen dalam menjelaskan variabel dependen dalam model. Pada penelitian ini nilai koefisien determinasi yang ditunjukkan pada tabel 4 adalah 0,700 atau sebesar $70 \%$. Hal ini menunjukkan bahwa persentase sumbangan dari variasi variabel independen yang digunakan dalam model (mental budget, self control, short term orientation, emotional instability, introvertion, conscientiousness, materialism, need for arousal dan debt adverse) mampu menjelaskan sebesar $70 \%$ variasi variabel dependen (credit card use). Sedangkan sisanya $30 \%$ dipengaruhi atau dijelaskan oleh variabel lain yang tidak dimasukkan dalam model penelitian ini.

Pada penelitian ini selanjutnya akan dilakukan uji kelayakan model (uji F). Uji $\mathrm{F}$ digunakan untuk menguji apakah model regresi yang digunakan sudah baik/signifikan atau sebaliknya. Dalam uji $F$, nilai $F_{\text {hitung akan }}$ dibandingkan dengan nilai $F_{\text {tabel, dan }}$ nilai signifikansi $(\alpha)$. Pengambilan keputusannya adalah apabila nilai signifikansi $<0.1(\alpha=10 \%)$. maka model regresi dikatakan layak, namun jika nilai signifikansi $>0.1(\alpha=10 \%)$, maka model regresi dikatakan tidak layak. Berdasarkan tabel 4 diperoleh nilai $\mathrm{F}_{\text {hitung }}=26.435$ dengan sign $=$ 0.000. Berdasarkan hasil pengujian tersebut, maka diperoleh kesimpulan nilai $F_{\text {hitung }}$ lebih besar $F_{\text {tabel }}(26.435>$ 1.694) dan nilai probabilitas nilai $F$ atau signifikan lebih kecil 10\% $(0.000<0.1)$ sehingga model regresi layak digunakan untuk penelitian. 


\subsection{Pengujian Hipotesis}

Tabel 5. Hasil Perhitungan Pengujian Hipotesis

\begin{tabular}{|l|r|c|c|}
\hline \multicolumn{1}{|c|}{ Variabel } & t hitung & Sign & Hasil Hipotesis \\
\hline Mental Budget & -1.735 & 0.086 & $\mathrm{H}_{1}$ diterima \\
\hline Self Control & -1.823 & 0.071 & $\mathrm{H}_{2}$ diterima \\
\hline Short Term Orientation & 3.991 & 0.000 & $\mathrm{H}_{3}$ diterima \\
\hline Emotional Instability & 2.117 & 0.037 & $\mathrm{H}_{4}$ diterima \\
\hline Introversion & -0.670 & 0.504 & $\mathrm{H}_{5}$ ditolak \\
\hline Conscientiousness & -2.618 & 0.010 & $\mathrm{H}_{6}$ diterima \\
\hline Materialism & 2.370 & 0.020 & $\mathrm{H}_{7}$ diterima \\
\hline Need for Arousal & -1.508 & 0.135 & $\mathrm{H}_{8}$ ditolak \\
\hline Debt Adverse & 7.332 & 0.000 & $\mathrm{H}_{9}$ diterima \\
\hline
\end{tabular}

Keterangan - signifikan pada level $\alpha=10 \%$

- $\mathrm{t}_{\text {tabel }}=1.659(\alpha=110 \%, \mathrm{df}=\mathrm{n}-\mathrm{k}-1(112-9-1)=102)$

\section{Hipotesis 1}

Berdasarkan hasil perhitungan yang ditunjukkan pada tabel 5 diperoleh nilai $t_{\text {statistik }}$ lebih kecil daripada $t_{\text {tabel }}(-$ $1.735<-1.659)$ dan nilai sig. lebih kecil dari $10 \%(0.086<0.1)$. Dengan demikian pengujian tersebut menunjukkan $\mathrm{H}_{1}$ diterima, variabel mental budget berpengaruh secara signifikan terhadap penggunaan kartu kredit. Adanya pengaruh mental budget terhadap penggunaan kartu kredit menunjukkan bahwa mental budget yang dimiliki oleh setiap individu berdampak pada pengaturan keuangannya termasuk dalam hal kredit. Hasil penelitian ini didukung oleh Perry (2000) yang menyimpulkan bahwa mental budget berpengaruh signifikan terhadap penggunaan kartu kredit.

\section{Hipotesis 2}

Berdasarkan hasil perhitungan yang ditunjukkan pada tabel 5 diperoleh nilai $\mathrm{t}_{\text {statistik }}$ lebih kecil daripada $\mathrm{t}_{\text {tabel }}(-1.823<$ -1.659) dan nilai sig. lebih kecil 10\% $(0.071<0.1)$. Dengan demikian pengujian tersebut menunjukkan $\mathrm{H}_{2}$ diterima, variabel self control berpengaruh secara signifikan terhadap penggunaan kartu kredit. Pengaruh self control terhadap penggunaan kartu kredit dibuktikan oleh beberapa penelitian sebelumnya yang menghubungkan masalah self control dengan penggunaan kartu kredit secara berulang dan belanja yang bersifat impulsif (Faber and O'Guinn 1988; Tokunaga 1993; Medina, et. al 1996. Self control merupakan salah satu cara agar seseorang terhindar dari masalah tersebut dimana mereka seharusnya 
merencanakan terlebih dahulu pembelian atau pengeluaran sehingga mereka tidak terjebak pada penggunaan kartu kredit yang tidak terencana. Dengan adanya pengendalian diri maka mereka akan terhindar dari pengelolaan keuangan yang buruk.

\section{Hipotesis 3}

Berdasarkan hasil perhitungan yang ditunjukkan pada tabel 5 diperoleh nilai $t_{\text {statistik }}$ lebih besar daripada $t_{\text {tabel }}$ $(3.991>1.659)$ dan nilai sig. lebih kecil $10 \%(0.000<0.1)$. Dengan demikian pengujian tersebut menunjukkan bahwa $\mathrm{H}_{3}$ diterima, variabel short term orientation berpengaruh secara signifikan terhadap penggunaan kartu kredit. Adanya pengaruh short term orientation terhadap penggunaan kartu kredit menunjukkan bahwa pentingnya seseorang untuk berorientasi ke masa depan. Seseorang yang hanya berorientasi jangka pendek relatif tidak memikirkan kebutuhan di masa yang akan datang. Individu dengan cakrawala waktu yang lebih pendek akan menjadi kurang peduli dengan biaya masa depan, seperti halnya saldo tagihan kartu kredit yang semakin tinggi atau biaya bunga kartu kredit yang semakin meningkat. Hasil penelitian ini didukung oleh Perry
(2000) dimana Perry menyarankan pentingnya penekanan psikologis seseorang terhadap orientasi di masa depan. Dengan tabungan atau investasi maka dapat memperbaiki kondisi keuangan seseorang.

\section{Hipotesis 4}

Berdasarkan hasil perhitungan yang ditunjukkan pada tabel 5 diperoleh nilai $t_{\text {statistik }}$ lebih besar daripada $t_{\text {tabel }}$ $(2.117>1.659)$ dan nilai sig. lebih kecil $10 \%(0.037<0.1)$. Dengan demikian pengujian tersebut menunjukkan bahwa $\mathrm{H}_{4}$ diterima, variabel emotional instability berpengaruh secara signifikan terhadap penggunaan kartu kredit. Emosi seseorang yang cenderung tidak stabil memiliki pengaruh untuk meningkatkan penggunaan kartu kredit. Hal ini dapat terjadi ketika seseorang tidak mampu menahan dirinya terhadap sesuatu atau barang yang diinginkannya padahal saat itu dirinya tidak memiliki uang yang cukup sehingga mereka cenderung berfikir bahwa kartu kredit adalah solusinya. Roberts (1998) menemukan bahwa penyalahgunaan kartu kredit adalah prediktor terkuat dari pembelian yang bersifat compulsive dan alasan penting di balik pembelian compulsive adalah untuk perbaikan suasana hati. 
Hasil penelitian ini didukung oleh Pirog and Robert (2007).

\section{Hipotesis 5}

Berdasarkan hasil perhitungan yang ditunjukkan pada tabel 5 diperoleh nilai $t_{\text {statistik }}$ lebih besar daripada $t_{\text {tabel }}(-$ $0.670>-1.659$ ) dan nilai sig. lebih besar $10 \%(0.504>0.1)$. Dengan demikian pengujian tersebut menunjukkan bahwa $\mathrm{H}_{5}$ ditolak, variabel introvertion berpengaruh secara signifikan terhadap penggunaan kartu kredit. Tidak adanya pengaruh dari sifat kepribadian introvertion terhadap penggunaan kartu kredit dapat dijelaskan bahwa seseorang cenderung bersikap terbuka dengan cara menerima informasi dari orang lain terutama yang berkaitan dengan kartu kredit. Dengan adanya sifat terbuka yang dimiliki oleh individu maka mereka dapat memperoleh informasi lebih mengenai kartu kredit, seberapa praktis dan mudahnya menggunakan karu kredit. Bahkan, tidak jarang diantara mereka akan tergoda dengan tawarantawaran yang diberikan kartu kredit seperti pembelian yang mendapat diskon tambahan ketika membayar dengan kartu kredit. Hal ini jelas berbeda dengan orang yang memiliki sifat lebih tertutup dimana mereka tidak mendapat informasi mengenai hal tersebut. Hasil pengujian ini didukung oleh penelitian Santoso (2012) sifat introvert tidak memiliki pengaruh yang signifikan terhadap penggunaan kartu kredit.

\section{Hipotesis 6}

Berdasarkan hasil perhitungan yang ditunjukkan pada tabel 5 diperoleh nilai $t_{\text {statistik }}$ lebih kecil daripada $t_{\text {tabel }}(-$ $2.618<-1.659)$ dan nilai sig. lebih kecil $10 \%(0.010<0.1)$. Dengan demikian pengujian tersebut menunjukkan bahwa $\mathrm{H}_{6}$ diterima, variabel conscientiousness berpengaruh secara signifikan terhadap penggunaan kartu kredit. Adanya pengaruh conscientiousness terhadap penggunaan kartu kredit menunjukkan bahwa pentingnya sikap cermat, berhatihati dan terorganisir. Dengan adanya sikap cermat dan berhati-hati di dalam diri seseorang maka akan cenderung menurunkan sikapnya terhadap penggunaan kartu kredit. Sikap conscientiousness akan menjadikan mereka lebih mempertimbangkan segala hal terutama dalam membuat keputusan keuangan. Hasil pengujian ini didukung oleh penelitian Santosa (2012) yang menyimpulkan bahwa sifat conscientiousness mampu mendorong individu untuk lebih mempertimbangkan 
resiko-resiko dari penggunaan kartu kredit bukan hanya melihat faktor kepraktisan dan kemudahan dari kartu kredit tersebut.

\section{Hipotesis 7}

Berdasarkan hasil perhitungan yang ditunjukkan pada tabel 5 diperoleh nilai $t_{\text {statistik }}$ lebih besar daripada $t_{\text {tabel }}$ $(2.370>1.659)$ dan nilai sig. lebih kecil $10 \%(0.020<0.1)$. Dengan demikian pengujian tersebut menunjukkan bahwa $\mathrm{H}_{7}$ diterima, variabel materialism berpengaruh secara signifikan terhadap penggunaan kartu kredit. Adanya pengaruh sifat materialism dalam diri seseorang cenderung meningkatkan penggunaan kartu kredit, hal ini ditunjukkan dengan sikap tidak terkendalinya seseorang atas kepemilikan suatu barang terutama bagi mereka yang menyukai barang bermerk dan mahal. Hasil penelitian ini didukung oleh Pirog and Robets (2007) yang menunjukkan bahwa sifat materialism hanya merujuk pada kepemilikan suatu barang yang dapat meningkatkan status sosial seseorang. Selama seseorang berusaha meningkatkan status sosialnya dengan cara kepemilikan suatu barang maka akan terjadi tingkat persaingan yang kompetitif, yang mana persaingan tersebut akan menjadikan seseorang tidak terkontrol untuk melakukan pembelian dan berbelanja. Ketika kegiatan pembelian ataupun pembelanjaan yang dilakukan tidak memiliki cukup uang maka kartu kredit menjadi solusinya "Buy Now, Pay Later".

\section{Hipotesis 8}

Berdasarkan hasil perhitungan yang ditunjukkan pada tabel 5 diperoleh nilai $t_{\text {statistik }}$ lebih besar daripada $t_{\text {tabel }}(-$ $1.508>-1.659)$ dan nilai sig. lebih besar $10 \%(0.135>0.1)$. Dengan demikian pengujian tersebut menunjukkan bahwa $\mathrm{H}_{9}$ ditolak, variabel need for arousal tidak berpengaruh secara signifikan terhadap penggunaan kartu kredit. Sifat dasar kepribadian need for arousal merupakan suatu sifat yang cenderung berambisi dan antusias maka dari itu sifat yang berambisi seperti ini akan memunculkan emosi yang positif dan negatif. Emosi positif terjadi ketika seseorang melakukan pembelian atau belanja terhadap produk baru yang dibelinya akan tetapi secara tidak langsung akan memunculkan emosi negatif ketika dirinya memikirkan tagihan yang akan tiap akhir bulannya. Belanja bisa dilihat sebagai kegiatan 
pemanjaan diri dan sebagai metode perbaikan suasana hati. Namun, belanja juga terkadang menimbulkan perasaan gelisah, tidak berdaya bahkan menghilangkan kontrol diri. Perasaan senang ketika berbelanja lalu mendapatkan barang yang diinginkan merupakan salah satu ciri individu yang memiliki kepribadian need for arousal. Hasil penelitian ini didukung oleh oleh Santosa (2012) yang menyimpulkan bahwa tidak adanya pengaruh need for arousal terhadap penggunaan kartu kredit.

\section{Hipotesis 9}

Berdasarkan hasil perhitungan yang ditunjukkan pada tabel 5 diperoleh nilai $t_{\text {statistik }}$ lebih besar daripada $t_{\text {tabel }}$ $(7.332>1.659)$ dan nilai sig. lebih kecil $10 \%(0.000<0.1)$. Dengan demikian pengujian tersebut menunjukkan bahwa $\mathrm{H}_{9}$ diterima, variabel debt adverse berpengaruh secara signifikan terhadap penggunaan kartu kredit. Adanya pengaruh debt adverse terhadap penggunaan kartu kredit menunjukkan bahwa seringkali seseorang menganggap kartu kredit bukanlah hutang akan tetapi salah satu cara untuk menghindari hutang. Lea et al (1995) menyimpulkan bahwa sifat debt adverse dalam diri seseorang menyatakan jika mereka tidak suka berhutang (misalnya: membeli barang akan tetapi belum lunas) namun mereka bersedia mengeluarkan biaya ekstra untuk menghindari hutang. Mereka lebih baik menggunakan kartu kredit untuk membayar barang secara lunas dibandingkan berhutang kepada penjual barang tersebut. Sifat negatif seperti ini yang terkadang tidak disadari dalam diri setiap individu. Mereka kurang menyadari bahwa kartu kredit merupakan bentuk lain dari hutang bahkan kartu kredit memiliki biaya ekstra (bunga) yang relatif tinggi. Seseorang mungkin tidak menyukai hutang akan tetapi mereka juga tidak melihat bahwa kartu kredit itu juga merupakan bentuk lain dari hutang.

\section{PENUTUP}

\subsection{Simpulan}

Dari uraian hasil penelitian ini, dapat disimpukan bahwa komponen dari mental accounting dan pshycological factors tidak seluruhnya berpengaruh signifikan terhadap penggunaan kartu kredit. Pada komponen mental accounting yang meliputi mental budget, self control dan short term orientation diperoleh bahwa ketiga indikator tersebut mempunyai pengaruh yang 
signifikan terhadap penggunaan kartu kredit. Hal ini dapat dikatakan bahwa akibat adanya penggunaan kartu kredit yang tidak terkendali dapat disebabkan oleh kecenderungan tinggi mental budget, kurangnya self control dan adanya orientasi jangka pendek dalam diri setiap individu. Dengan ditemukannya pengaruh mental accounting terhadap penggunaan kartu kredit dari hasil analisis maka dapat disimpulkan bahwa rumusan masalah pertama dari penelitian ini telah terbukti.

Selain memprediksi pengaruh mental accounting penelitian ini juga melakukan prediksi terhadap adanya pengaruh pshycological factors terhadap penggunaan kartu kredit. Faktor psikologi yang diuji terdiri dari dari personality traits yang mencangkup emotional instability, introvertion, conscientiousness, materialism dan need for arousal; serta attitude toward debt yang mencangkup debt-adverse. Hasil analisis menyimpulkan bahwa hanya variabel emotional instability, conscientiousness, materialism dan debtadverse yang mempunyai pengaruh signifikan terhadap penggunaan kartu kredit.

Dari hasil temuan ini diperoleh bahwa emotional instability (ketidakstabilan emosi), materialism (materialisme) dan debt-adverse (sikap enggan berhutang) memiliki pengaruh negatif atau cenderung meningkatkan penggunaan kartu kredit sedangkan conscientiousness (sikap berhati-hati) memiliki pengaruh positif atau cenderung menurunkan penggunaan kartu kredit. Akan tetapi pada variabel introvertion dan need for arrousal tidak memiliki pengaruh terhadap penggunaan kartu kredit. Individu yang cenderung bersifat introvertion (sifat tertutup), seringkali tidak memperoleh informasi lebih sehingga mereka tidak tergoda oleh benefit yang ditawarkan oleh kartu kredit. Pada sifat need for arousal (antusias) dapat disimpulkan bahwa kebanyakan orang tidak menyukai resiko yang tinggi khususnya dalam hal pengelolaan keuangannya.

\subsection{Saran}

Penelitian ini memberikan peluang untuk peneliti selanjutnya, baik dari sisi issu, metode riset, maupun teori yang digunakan. Hal ini dikarenakan masih terbatasnya penelitian yang membahas mental accounting secara mendalam khususnya di Indonesia. Pada dasarnya, komponen mental accounting juga tidak hanya mencangkup mental budget, self 
control dana short term orientation. Sehingga, penelitian ini sebenarnya masih dapat dikembangkan lebih jauh lagi dengan menambahkan faktor-faktor lainnya yang diprediksi mampu memberikan pengaruh terhadap penggunaan kartu kredit.

\section{DAFTAR PUSTAKA}

Black, S. E. and D. P. Morgan (1998). "Meet the New Borrowers". Current Issues in Economics and Finance. Federal Reserve Bank of New York: 5(3).

D’Astous, A. (1990). “An Inquiry Into The Compulsive Side of 'Normal' Consumers." Journal of Consumer Policy, 13(1): 15-31.

Faber, R. J and T. C. O'Guinn (1988). "Compulsive Consumption and Credit Abuse". Journal of Consumer Policy, 11: 97-109.

Ghozali, I. (2005). “Aplikasi Multivariate dengan Program SPSS." Badan Penerbit Universitas Diponegoro, Semarang.

Hirschman, E. C. (1979). “Differences In Consumer Purchase Behavior By Credit Card Payment System." Journal of Consumer Research: 5866.
Hoch, S. J. and G. F. Loewenstein (1991).

"Time-Inconsistent Preferences and Consumer SelfControl." Journal of Consumer Research: 492-507.

Lea, S. E., et al. (1995). "Psychological Factors in Consumer Debt: Money Management, Economic Socialization, and Credit Use." Journal of Economic Psychology. 16(4): 681-701.

Loewenstein, G. and R. H. Thaler (1989). “Anomalies: Intertemporal Choice." The Journal of Economic Perspectives Volume 3, Number 4: 181-193.

Medina, et. al. (1996). "Comparison and Mexican-American and AngloAmerican Attitudes Toward Money", Journal of Consumer Affairs, 122-145.

Mowen, J. C. (2000). “The 3M Model of Motivation and Personality:Theory and Empirical Application to Consumer Behavior." Boston: Kluwer Academic.

Perry, V. G. (2000). “Antecedents of Consumer Financing Decisions: A Mental Accounting Model of Revolving Credit Usage." Ann Arbor, The University of North Carolina at Chapel Hill. 
Pirog, S. F., III and J. A. Roberts. (2007). "Personality and Credit Card Misuse Among College Students: The Mediating Role of Impulsiveness." Journal of Marketing Theory and Practice 15(1): 65-77.

Roberts, J. A. (1998). "Compulsive Buying Among College Students: An Investigation of Its Antecedents, Consequences, and Implications for Public Policy." The Journal of Consumer Affairs, 32 (2): 295-319.

Santosa, Y. D. (2012). "Pengaruh Personality Traits terhadap Penggunaan Kartu Kredit dengan Locus of Control sebagai Variabel Moderating (Studi terhadap Karyawan PT. Kinocare Era Kosmetindo Jakarta)". Program Studi Manajemen FEB-UKSW.

Sugiyono, D. (2010). “Metode Penelitian Kuantitatif Kualitatif dan $R \& D ”$. Penerbit Alfabeta.

Thaler, R. H. (1999). "Mental Accounting Matters." Journal of Behavioral Decision Making 12(3): 183-206.

Thaler, R. H. and H. M. Shefrin (1981). "An Economic Theory of Self-
Control." Journal of Political Economy 89(2): 392-406.

Tokunaga, H. (1993). "The Use and Abuse of Consumer Credit: Applications of Psychological Theory and Research." Journal of Economic Psychology, 14(2), 285316. 